\title{
Robert Sobiech
}

\section{Trust in government in times of economic crisis}

\begin{abstract}
The aim of the paper is to provide an overview of the existing studies concerning the phenomenon of public trust in government. Low trust in government has been frequently defined as a key problem influencing the policy process in many countries. The economic crises reinforced the importance of trust and triggered public debates on the necessary reforms of the public sector. The paper examines the key theories and research conducted by social scientists with a particular emphasis on the role of trust in risk societies. The review of the existing literature concentrates on the drivers of trust, showing the importance of two interlinked logics: the logic of consequences (the performance approach) and the logic of appropriateness (the process approach). The first one explains trust as a result of outputs and outcomes of government policies and services. The logic of appropriateness claims that trust is built on values and identity and depends on the adoption by governments the rules of integrity, openness, responsiveness and transparency. Trust in government is also deeply rooted in a broader system of rules, norms and values known as the trust culture. The last part of the paper is an attempt to trace an impact of an economic crisis on public trust. Studies of public opinion do not fully confirm the opinions on low trust and a decline in trust in government and trust in public administration in times of crisis. Some studies reveal considerable fluctuations of public trust in selected countries. In other countries, the public evaluation of government and public administration is high and there are only slight modifications in citizens' perception of the government.
\end{abstract}

Keywords: trust, government, public administration, civil service, public opinion, risk society. 


\section{Zaufanie do władz publicznych w warunkach kryzysu}

\section{Streszczenie}

Celem artykułu jest dokonanie przeglądu współczesnych badań poświęconych zjawisku publicznego zaufania do władz publicznych. W wielu państwach niski poziom tego zaufania jest często uznawany za kluczowy czynnik determinujący proces polityki publicznej. Kryzys ekonomiczny ukazał w pełni znaczenie zaufania, inicjując publiczne debaty na temat koniecznych reform sektora publicznego. Tekst przedstawia kluczowe teorie dotyczące roli zaufania w społeczeństwach ryzyka i wyniki prowadzonych przez przedstawicieli nauk społecznych badań koncentrujących się na tym właśnie temacie. W przeglądzie literatury szczególnie wyeksponowano zagadnienie uwarunkowań zaufania, ukazując znaczenie dwóch powiązanych ze sobą podejść; logiki konsekwencji (uwypuklającej znaczenie wyników działalności władz publicznych) oraz logiki stosowności (uwypuklającej proces działania). Pierwsze podejście wyjaśnia zaufanie jako efekt polityk i usług oferowany przez władze publiczne. Przy drugim zakłada się, że zaufanie jest budowane na wartościach i tożsamości oraz zależy od tego, w jakim stopniu władze publiczne realizują zasady uczciwości, otwartości, elastyczności i przejrzystości. Zaufanie do władz publicznych jest także głęboko zakorzenione w systemie norm i wartości, określanych jako kultura zaufania. W ostatniej części artykułu podjęto próbę analizy wpływu kryzysu ekonomicznego na zaufanie do władz publicznych. W wielu państwach badania opinii publicznej nie potwierdzają w pełni poglądów o niskim poziomie zaufania do rządu i administracji publicznej czy jego spadku w czasach kryzysu. W niektórych krajach badania wykazują znaczące fluktuacje zaufania, w innych mamy do czynienia z wysokimi ocenami rządu i administracji publicznej oraz jedynie niewielkimi zmianami w postrzeganiu władz publicznych przez obywateli.

Słowa kluczowe: zaufanie, rząd, administracja publiczna, służba cywilna, opinia publiczna, społeczeństwo ryzyka.

\section{Trust in risk society}

"The financial and economic crisis that started in 2008 led to a significant loss of trust in government. By 2012, on average only four out of ten people in OECD member countries expressed confidence in their government. As governments search for a path to economic recovery, the challenge they face is not only knowing what policies to choose, but also how to implement those policies. Yet, the capacity to implement depends crucially on trust. Without trust in governments, markets and institutions, support for necessary reforms is difficult to mobilize, particularly where short-term sacrifices are involved and long-term gains might be less tangible. The 
sharp decline in trust in government is serving to underline that trust is an essential, yet often overlooked, ingredient in successful policy making ${ }^{1 "}$. The OECD interest in trust dates back to the early $2000 \mathrm{~s}$ when trust was selected as one of the key drivers of public sector reforms $s^{2}$. The turbulent times of the economic crisis reinforced the importance of trust in governments. In 2010 trust was considered as "an overarching goal to foster an effective and performance-driven public sector ${ }^{3 \text { ". }}$

In the last five decades the phenomenon of trust has become subject to extensive research conducted by social sciences (economics, social psychology, sociology, political science, public management, public administration $)^{4}$. The interest in trust resulted in a variety of theoretical approaches and empirical research ${ }^{5}$. In the late $1990 \mathrm{~s}$ the social and economic changes triggered by the processes of globalization and modernization have significantly increased the number of studies concerning trust $^{6}$. The widespread interest in the phenomenon of trust, the variety of theoretical perspectives have made trust one of the most popular concepts in social sciences. On the other hand, there is very little agreement how to define trust ${ }^{7}$.

The economic crisis affecting the industrialized countries in recent years draws a special attention to understanding trust in a broad context of newly or previously identified risks. The concept of the risk society was developed in late 1990 as a reaction to the modernization processes, which significantly reshaped the social structure of contemporary societies. Beck defines the risk society as "a systematic way of dealing with hazards and insecurities induced and introduced by modernization itself" . According to Giddens ${ }^{9}$, the main characteristic of a risk society is the preoccupation with the future, which generates the notion of risk. In an economic crisis, the effects of modernization have been partly replaced with a number of specific threats

1 Trust in government, policy effectiveness and the governance agenda, in: Government at a Glance, OECD Publishing, 2013, p. 20.

2 Public sector reform: The way forward, OECD, Paris 2005.

3 The call for innovative and open government. An overview of national initiatives, OECD, Paris 2011, p. 3.

4 T. Tyler, Why people obey the law, Yale University Press, New Haven 1990; L.G. Zucker, Production of trust: Institutional sources of economic structure 1840-1920, "Research in organizational behavior" 1986, Vol. 8, pp. 53-111; O.E. Williamson, Calculativeness, Trust and Economic Organization, "Journal of Law and Economics" 1993, Vol. 30, pp. 131-145.

5 D.M. Rousseau, S.B. Sitkin, R.S. Burt, C. Camerer, Not so Different after all: A Cross-Discipline View of Trust, "Academy of Management Review" 1998, Vol. 23(3), pp. 393-404.

6 Trust in Society, ed. K.S. Cook, Russel Sage Foundation, New York 2001; A. Giddens, The Consequences of Modernity, Polity, Cambridge 1990.

7 S.E. Kim, The Role of Trust in the Modern Administrative State: An Integrative Model, "Administration \& Society" 2005, Vol. 37, pp. 611-635; P. Sztompka, Trust, Distrust and Two Paradoxes of Democracy, "European Journal of Social Theory" 1998, Vol. 1(1), pp. 19-32.

8 U. Beck, Risk Society: Towards a New Modernity, Sage, New Delhi 1992, p. 21.

9 A. Giddens, Risk and Responsibility, "Modern Law Review” 1999, Vol. 62(1), pp. 1-10. 
to the well-being of many societies. According to some scholars, trust is needed only in risky or contingent situations and to trust someone usually means to take risk with the trustee ${ }^{10}$.

One can claim that risk understood as "a condition in which the consequences of a decision and the probabilities associated with the consequences are known entities"11 has become a permanent part of everyday life in a period of economic crisis. Therefore, trust in the public sector, especially trust in the government capable of protecting an ordinary citizen from the consequences of an economic recession or reducing the scope of risks faced by the citizens, has been placed on the agenda of national governments and international organizations.

The body of research into institutional trust concerns the phenomenon of trust in the public sector and trust in government. One of the key controversies is the question of a social definition of these concepts. To some people the public sector can be understood in a broad sense, as a combination of the civil service (the government and local public administration), executive and legislative politicians along with the judicial system. For others, it can be associated with executive power (politicians and civil servants) or with civil service and its administrative component, exclusively. Similar controversies concern the definition of government. Some scholars argue that people see government as one amorphous unity, associated with a general political system or with an incumbent government currently holding political offices. Others ${ }^{12}$ claim government is perceived (and evaluated) mainly in terms of a specific public service provided to the citizens. The discussion on generalization versus differentiation ${ }^{13}$ has had a significant impact on the conceptions explaining the drivers of public trust.

\section{Drivers of trust}

The body of the existing literature concerning the causes of trust, focuses on two dominant approaches. The first one, the performance approach, explains trust

10 J.S. Coleman, Foundations of Social Theory, Harvard University Press, Cambridge 1990; N. Luhmann, Trust and Power, John Wiley \& Sons, Chichester 1979; T.K. Das, S. Teng Bing, The Risk-Based View on Trust: A Conceptual Framework, "Journal of Business and Psychology" 2004, Vol. 19(1), pp. 85-116.

${ }^{11} \mathrm{I}$. Baird, H. Thomas, Toward a contingency model of strategic risk taking, "Academy of Management Review" 1985, Vol. 10, p. 231.

12 H.D. Klingemann, Mapping Political Support in the 1990s: A Global Analysis, in: Critical Citizens: Global Support for Democratic Governance, ed. P. Norris, Oxford University Press, Oxford 1999, pp. 31-56.

${ }^{13}$ G. Bouckaert, S. Van de Walle, B. Maddens, J. Kampen, Identity vs. performance: An overview of theories explaining trust in government. Second report: Quality and trust in government, Public Management Institute, Leuven 2002. 
as a result of government performance with a particular emphasis on outputs and the process of government policies and services. The dominant assumption of the performance approach links public trust with the outcomes and outputs of government activity. Public trust depends on the government's ability to provide high-quality social services, achieve the outcomes that ameliorate the most acute social problems or enhance the well-being of the society. From this perspective, social attitudes toward government are shaped by the citizens' satisfaction with the services offered in such areas as health, education, culture, by the citizens' evaluation of key public policies aimed at reducing unemployment, crime, poverty, and, last but not least, by the overall assessments of social or economic development. Nevertheless, many studies testing the linkage between trust in government and policy outputs or outcomes show ambiguous results ${ }^{14}$. Comparative research conducted in many European countries and in the United States reveal that a decrease in trust in government often corresponds with a high satisfaction with public services ${ }^{15}$.

"The contemporary performance movement has tended to assume that a key to restoring public trust in civil servants lies in the focus on outcomes or results. But there is growing evidence from various fields that trust in people and institutions of authority often depends more on process (such as fairness and equity) than on outcomes" ${ }^{16}$. The rediscovery of the importance of the process in the formation of trust judgments has been a significant contribution to the studies on public trust. Hibbing and Theiss-Morse, summarizing the findings of their study, conclude that there is a close match between the approval for government and people's preferences on the process the government follows ${ }^{17}$. The acknowledgement that citizens' evaluation of government are driven not only by policy outcomes draw the attention to understanding the exiting expectations concerning the governmental process.

Several studies dealing with the reconstruction of people's expectations present a number of process components, which influence public trust in government. The $\mathrm{OECD}^{18}$ has proposed the following typology:

\footnotetext{
14 S.G. Ulbig, Policies, Procedures, and People: Sources of Support for Government, "Social Science Quarterly" 2002, Vol. 83, pp. 789-809.

15 J.S. Nye, The Decline of Confidence in Government, in: Why People Don't Trust Government, eds J.S. Nye, P.D. Zelikow, D.C. King, Harvard University Press, Cambridge 1997; A.H. Miller, O. Listhoug, Policy Preferences and political distrust: A Comparison of Norway, Sweden and the United States, "Scandinavian Political Studies" 1998, Vol. 21, pp. 161-187.

16 G. Van Ryzin, Outcomes, Process, and Trust of Civil Servants, "Journal of Public Administration Research and Theory" 2011, Vol. 21, Issue 4, p. 747.

17 J.R. Hibbing, E. Theiss-Mors, Stealth Democracy: Americans' Beliefs About How Government Should Work, Cambridge University Press, Cambridge 2002.

18 Trust in government..., op.cit.
} 
- Reliability: the ability of governments to minimize uncertainty in the economic, social and political environment of their citizens, and to act in a consistent and predictable manner.

- Responsiveness: the provision of accessible, efficient and citizen-oriented public services that effectively address the needs and expectations of the public.

- Openness and inclusiveness: a systemic, comprehensive approach to institutionalizing a two-way communication with stakeholders, whereby relevant, usable information is provided, and interaction is fostered as a means to improve transparency, accountability and engagement.

- Integrity: the alignment of government and public institutions with broader principles and standards of conduct that contribute to safeguarding the public interest while preventing corruption.

- Fairness: in a procedural sense the consistent treatment of citizens (and businesses) in the policy-making and policy-implementation processes.

For Halligan and Bouckaert studies on public trust should include two interlinked logics: "logic of consequences" and a "logic of appropriateness" ${ }^{19}$. Within the logic of consequences, trust is shaped on the belief that government (public administration) resources, solid management and policy instruments lead to good performance, which contribute to further trust. Within the logic of appropriateness, trust is built on values and identity, which may lead to the adoption by government the rules of: integrity, openness, responsiveness and transparency, which may, in turn, lead to better performance and to a further increase in trust.

The second approach focuses on the role of social factors in influencing public trust. In the recent decades, sociological studies on trust have strongly been influenced by the concepts of post-materialism and modernization. Post-materialism, as one of the most influential perspectives, stresses the role of social changes occurred in an industrialized society ${ }^{20}$. The shift of individual values from materialist, physical and economic to the values of autonomy and self-expression and self-esteem has modified social expectations toward government. On the one hand, government is expected to be responsive to the newly defined or occurred problems, on the other hand, it should ensure public participation in the decision-making process. The latter implies that different citizens' representations will take the position of an important stakeholder, evaluating the government's activities with relation to their normative orientations and identities.

19 J. Halligan, G. Bouckaert, Performance and trust: Developmental paths and optional directions, in: Change and continuity in public sector organizations - essays in honour of Per Loegreid, eds P.G. Roness, H. Sætren, Fagbokforlaget, Bergen 2009, pp. 257-277.

20 R. Inglehart, Culture Shift in Advanced Industrial Society, Princeton University Press, Princeton 1990. 
Some scholars put a particular emphasis on the effects of the modernization process. The widely shared beliefs in the government's abilities to ameliorate the existing problems result in an individual or group incapability to deal with risk ${ }^{21}$. The incapability in responding to risk situations co-occurs with the growing complexity of modern societies. As a result, citizens become more dependent on government interventions. There is also a strong demand for the implementation of stable and transparent procedures and rules, which will reduce the uncertainty and ensure the control over people's lives.

Trust in government or trust in the public sector are deeply rooted in a broader system of rules, norms and values known as the trust culture. The trust culture regulates both granting trust as well as reciprocating trust. According to Sztompka, the emergence of the trust culture depends on several macro-societal circumstances like: normative coherence, as opposite to normative chaos, stability of the social order, as opposed to radical change, transparency of the social organization, as opposed to the pervasive secrecy, familiarity, or its opposite, the strangeness of the environment in which people operate and the accountability of other people and institutions, as opposed to arbitrariness and irresponsibility. The transparency of the social organization and the accountability of institutions seem to play a key role in shaping trust in government. In case of the public sector, transparency involves the availability of information about the functioning institutions, which, in turn, provides the feeling of security and predictability. "People are apt to relate to them with trust, because they are assured about what they may expect"22. The accountability of institutions depends on their ability to set standards, provide checks and control. "If people can resort to such institutions when their rights are not recognized, or the obligations of others toward them not respected, then they acquire a kind of insurance, backup option and therefore feel safer. Everybody is confident that standards will be observed, departures prevented, and that even if abuse occurs it will be corrected by recourse to litigation, arbitration, restitution etc." ${ }^{23}$. The trust culture determines a nation's capacity to develop the institution responsible for its economic and social development. The success of high-trust nations and development problems faced by low-trust countries have been presented in many studies, inspired by Fukuyama's theory ${ }^{24}$. (Fukuyama 1995).

${ }^{21}$ A. Giddens, The Consequences of Modernity, Cambridge University Press, Cambridge 1996.

22 P. Sztompka, Trust: A cultural resource, in: The Moral Fabric in Contemporary Societies, eds G. Skapska, A. Orla-Bukowska, K. Kowalski, "The Annals of International Institute of Sociology. New series" 2003, Vol. 9, p. 53.

${ }^{23}$ Ibidem.

${ }^{24}$ F. Fukuyama, Trust: The social virtues and the creation of prosperity, Free Press, New York 1995. 
The existing literature provides many concepts which link the performance approach with socio-cultural interpretations of trust. Trust is defined as a result of a rational calculation, emotional attitudes, the institutional environment and cultural influences. Klingemann claims that the key role in citizens' evaluation of government play moral, emotional (expressive) and rational (instrumental) criteria. The rational evaluation usually concerns the assessment of government performance, while moral and emotional criteria strongly influence general attitudes towards government ${ }^{25}$. Ringeling ${ }^{26}$ distinguishes the following criteria: instrumental (effectiveness, efficiency), bureaucratic (legality, justice, possibilities for discretion in policy), contingency (representativity, receptiveness) and symbols/values (political order, distribution of values).

The OECD report (OECD 2013) identifies four groups of drivers of trust in government: 1) culture; 2) institutional setting; 3 ) economic and social outcomes; and 4) performance of institutions. According to the OECD report "while there is more or less a consensus on the range of drivers involved, the evidence is conflicting on the magnitude of their influence and the depth of their reciprocal relationship with trust. A general finding is that trust and most of its drivers are interlinked and self-fulfilling"27.

For Bouckaert ${ }^{28}$ trust in government should be explained at three interlinked levels: the macro-level, where trust relates to political institutions and the functioning of democracy, the meso-level, where trust relates to policy making (the ability of governments to manage economic and social issues) and the micro-level, where trust is influenced by the government's activity on people's daily lives through service delivery. As Bouckaert notes, these three levels interact and a significant lag in trust at one level may affect trust at other levels and influence policy outcomes.

The theoretical perspectives show the complexity of the phenomenon and the numerous challenges the research into trust faces. They also convince that citizens' declarations of trust or distrust in government, should be interpreted as a result of a multidimensional interaction of culture patterns values, knowledge, needs, and everyday experiences, comprising an overall image of government. Theories explaining trust in government can be applied to understand social attitudes towards public administration.

\footnotetext{
${ }_{25}$ H.D. Klingemann, op.cit.

${ }^{26}$ G. Bouckaert, S. Van de Walle, B. Maddens, J. Kampen, op.cit., p. 43.

27 Trust in government..., op.cit., p. 28.

${ }^{28}$ Ibidem.
} 


\section{Is there a decline in trust?}

Numerous studies on public attitudes do not fully confirm the widespread opinions about low trust and a decline in trust in government and trust in public administration $^{29}$. Some studies reveal considerable fluctuations of public attitudes in selected countries. In other countries, the public assessment of government administration is high and there are only slight modifications in the public perception and the level of credibility. In other countries, the public assessment of government administration is high and there are only slight modifications in the public perception and the level of credibility. Some studies show that a well-functioning public sector is necessary, but not sufficient for building trust in the public sector as there is no evidence of a direct causal link between the performance of government and citizens' trust in government. Negative opinions on public administration can often coincide with a positive evaluation of specific services ${ }^{30}$.

The OECD report on the impact of an economic crisis on trust in government shows that the share of the respondents expressing confidence in national government in 2012 was lower on average by five percentage points than in 2007. However, the report reveals considerable differences in the modification of public attitudes in selected countries. "More than two-thirds of OECD countries reported a loss of confidence in government from 2007 to 2012. The larger drops in trust occurred in countries facing either a political, fiscal or economic crisis, such as Greece, Slovenia. Ireland, Spain, Belgium and Portugal. In other countries, however, confidence in government increased, notably in the Slovak Republic, Israel, the United Kingdom, Poland, France, Switzerland, Germany, and Sweden"31.

Studies of public opinion systematically conducted in the European Union countries reveal that trust in public administration (bulk of the studies refer to the term civil service) also differs significantly and has undergone considerable transformations in some countries. The data from two waves of European Values Survey ${ }^{32}$ (Fig. 1), conducted at the beginning and at the end of the 2000 s (e.g. the first phase of the

${ }^{29}$ S. Van de Walle, S. Van Roosbroek, G. Bouckaert, Strengthening Trust in Government: What Role for Government in the 21st Century: Annex: Data on trust in the public sector, Analytical annex prepared for the OECD meeting of the Public Governance Committee at ministerial level, Rotterdam 2005, https:// lirias.kuleuven.be/bitstream/123456789/84459/1/OECD_trust_public_sector.pdf.

${ }^{30}$ R. Sobiech, Image and Attractivity of Central Government Administrations, A Report for European Social Dialogue Committee in Central Government Administrations, 2012, p. 16, http://www.epsu. org/IMG/pdf/Image_CGA_report_17122012_EN.pdf.

${ }^{31}$ Trust in government..., op.cit., pp. 26-27.

32 European Values Study, http://www.europeanvaluesstudy.eu. 
economic crisis) show a high level of confidence ${ }^{33}$ in the civil service in Luxemburg, France and Belgium, with a level of confidence in the civil service as high as around $60 \%-70 \%$ of the surveyed citizens ${ }^{34}$. (Sobiech 2013:11). Moreover, during the last 10 years a significant increase in public trust was reported in these countries. The similar high level of public trust was reported in Slovenia with the biggest rise in confidence (from 25\% to 55\%). The United Kingdom, Finland, Spain and Hungary constitute a group of countries where confidence in the civil service is found amongst $40 \%-46 \%$ citizens. The level of support seems to be stable except Hungary where a significant loss of trust in the civil service occurred during the last decade.

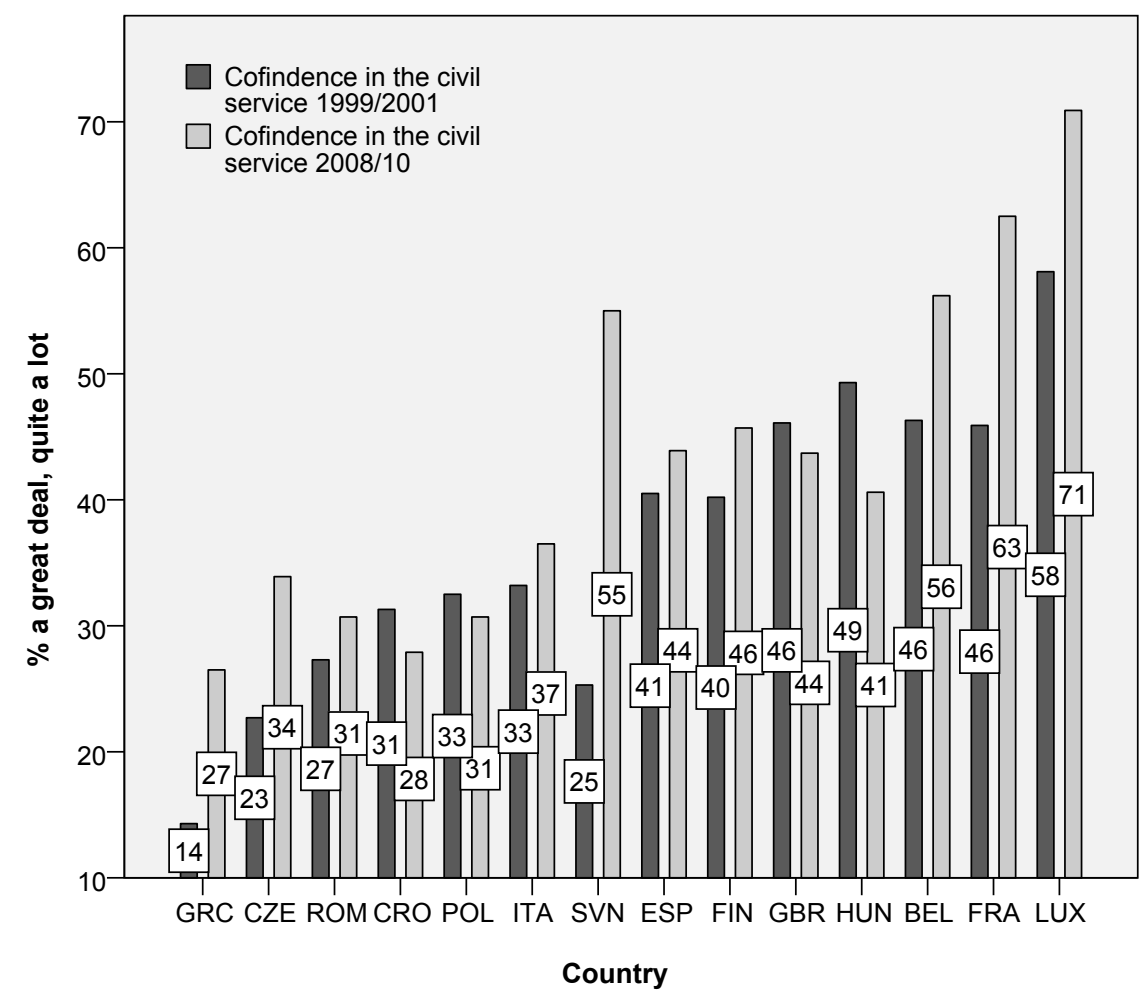

Figure 1. Confidence in the civil service

Source: European Values Survey.

On the other hand, in the Czech Republic Romania, Poland and Italy only around one third of the citizens have confidence in the civil service. The lowest level

${ }^{33}$ In the European Values Survey the term "confidence" was used.

${ }^{34}$ R. Sobiech, op.cit., p. 11 
of confidence is reported in Greece. At the beginning of the decade only $14 \%$ of the Greeks trusted their administration. Around ten years later, despite the significant increase in trust, Greece remains the country with the lowest level of confidence in the civil service.

Trust in the civil service is only partially related to trust in government. In the majority of the countries studied, trust in the civil service is higher than trust in government (Fig. 2). In some countries like France and Hungary the level of trust in the civil service double the level of trust in government. Only in Finland, trust in government is higher than trust in the civil service.

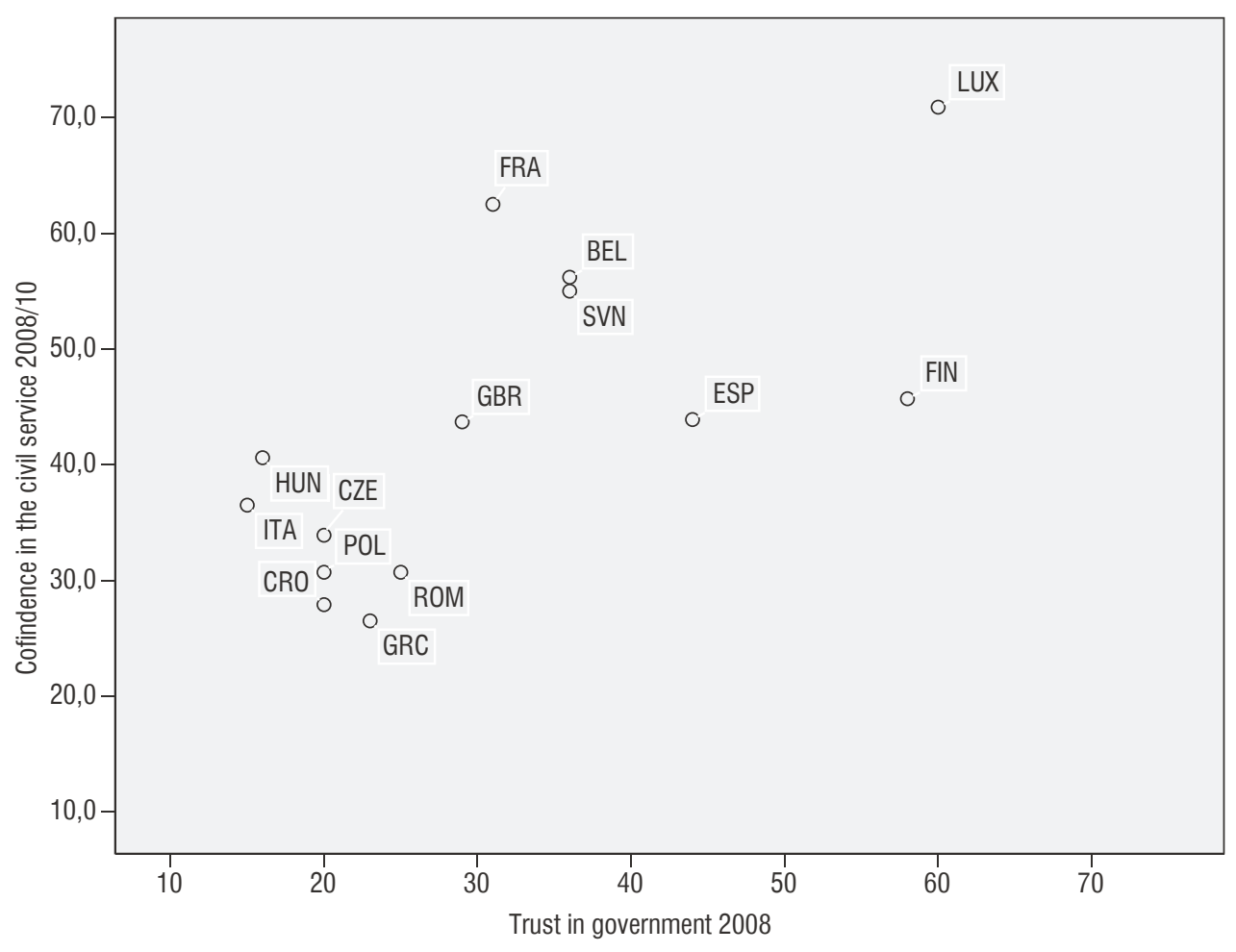

Figure 2. Trust in the civil service and trust in government

Source: European Values Survey.

The level of public trust differs depending on the public administration tradi$\operatorname{tion}^{35}$. A relatively high level of public trust is reported in countries of a Continental

${ }^{35}$ Ch. Demmke, T. Henökl T. Moilanen, What are Public Services Good at? Success of Public Services in the Field of Human Resource Management, Study Commissioned by the Slovenian EU Presidency, Report 
public administration tradition (on average, $61 \%$ of citizens declare confidence in the civil service), while the low level of trust characterizes Eastern European countries (31\%). In countries of the Mediterranean model, the level of trust is slightly higher than in Eastern Europe (41\%).

Comparisons of confidence in the civil service with selected OECD indicators ${ }^{36}$ of socio-economic development ${ }^{37}$ show that public trust in the civil service is related with the conditions of living, the disparities in the national wealth distribution as well as with the acceptance for democracy and its institutions. Trust in the civil service is higher in higher-income countries (Luxemburg, France, Belgium, Slovenia) and lower in less affluent societies (Poland, Greece, the Czech Republic, Hungary).

The diverse opinions concern citizens' evaluation of public administration. In the Eurobarometer polls on social climate ${ }^{38}$ ("Social Climate", 2011), the respondents were asked about the way public administration is run in their country. In the period of 2008-2011, Luxemburg, Finland and Belgium were the countries of the highest citizens satisfaction (more that $55 \%$ positive opinions). The most pessimistic assessment was reported in Greece and Romania. In these countries fewer than $10 \%$ of the citizens were of the opinion that the way public administration is run is very good or rather good, and the percentage of positive responses had dropped significantly in the last 3 years. Despite the financial crisis, in the period of 2008-2011 the opinions on the functioning of public administration improved in the majority of the countries. The highest increase in positive assessment was reported in Luxemburg and in Italy. In October 2011, $60 \%$ of the Greeks and $41 \%$ of the Romanians expected that the functioning of public administration would deteriorate in the next 12 months. In contrast, in Luxemburg, Finland and Poland, fewer than $20 \%$ of the respondents declared that the next 12 months would be worse concerning the way public administration is run. In contrast, in Luxemburg, Finland and Poland, fewer than $20 \%$ of the respondents declared that the next 12 months would be worse concerning the way public administration is run $^{39}$.

The changes reported by Eurobarometer surveys were confirmed by some national studies. For example, in Italy the overall evaluation on the Italian public administration has significantly improved in the last 2 years. In 2009, 29\% of the Italians had a positive opinion on public administration. In $2011,41 \%$ of the respondents expressed

to the 50th Meeting of the Directors-General of Public Services of the Member States of the European Union, 2008, http://www.eupan.eu/files/repository/Success_of_public_services_in_HRM.pdf.

$36 \mathrm{http} / / /$ www.oecd-ilibrary.org/statistics.

${ }^{37}$ R. Sobiech, op.cit,

38 Social Climate, Special Eurobarometer 370, The European Commission, 2011, http://ec.europa. eu/public_opinion/archives/ebs/ebs_370_en.pdf.

${ }^{39}$ R. Sobiech, op.cit., p. 13. 
a positive opinion. The areas of particular improvement were: the relations between the citizens and the public administration (a rise of 19.3\%), health (16.6\%); public transport (13.5\%) and education (11.9\%). The rise in positive evaluation was also reported in the case of tax administration, public insurance, welfare and employment. A slightly different picture is presented by the data on the perception of the changes in the efficiency of public administration in the last 3 years. Positive changes were indicated only by $37 \%$ of the respondents. Almost half of the Italians (46\%) had not observed any improvement and $17 \%$ claimed that the situation had worsened ${ }^{40}$.

Some research revealed that citizens' assessment of the public administration functioning seems to reflect satisfaction with the delivery of a specific public service. The Eurobarometer data showed that in some countries the general assessment of public administration was interrelated with the satisfaction with public services. For example, a positive assessment of health care provision appeared more frequently in the countries where the public administration functioning was highly evaluated $^{41}$. In Belgium - a country with one of the highest levels of positive evaluation of public administration, $95 \%$ of the respondents were satisfied with the health care provision. The same situation applied to Luxemburg, Finland and, to some extent, to the U.K.. Greece and Romania - i.e. the countries with an extremely low level of positive assessment of public administration had also the lowest level of satisfaction with the health care provision (22\% of the respondents in Greece and $13 \%$ of the respondents in Romania). A similar situation appeared when the opinions on the public administration functioning were confronted with the opinion on the policies addressed to specific social groups (for example, the opinions on the way the issues of inequality and poverty are addressed).

Generally, the negative opinions on public administration are modified when they relate to the direct experience the citizens have with that public administration. The shorter the distance (both in the symbolic space and in real conditions) between the citizens and the public administration, the better the assessment of the latter's performance, the greater the satisfaction with the service delivered and the higher, more positive evaluation of the civil servants. In many cases, surveys on users' satisfaction present a more positive assessment of public services than studies on citizens' general perceptions of such services. Most of the citizens who have had

${ }^{40}$ L. Massoli Building Image of Public Administration: Practices and data from Italy, Public Administration Department, Innovative Public Services Group Meeting, Presidency of the Council of Ministers, Warsaw September 2011, Fact sheet presented to the Polish Presidency by the EUPAN Members' administrations.

${ }^{41}$ Social Climate..., op.cit. 
a direct contact with civil servants perceive them as honest; competent, dedicated to public service and aware of the sense of service ${ }^{42}$.

Trust in the civil service is deeply rooted in the specific institutional context of each country and reflects the complex citizen-state relations. The level of public trust depends on the public administration tradition (the lowest trust in Eastern European countries) and it is closely related to the level of socio-economic development (the lowest trust in less affluent societies). Therefore, trust seems to be an outcome of long-term processes, through which the socio-cultural patterns have been shaped. On the other hand, many national studies provide convincing evidence showing a strong correlation between trust in public administration (or in the government as a whole) and national policies' outputs and processes.

\section{References}

Baird I., Thomas H., Toward a contingency model of strategic risk taking, "Academy of Management Review" 1985, Vol. 10.

Beck U., Risk Society: Towards a New Modernity, Sage, New Delhi 1992.

Bouckaert G., Van de Walle S., Maddens B., Kampen J., Identity vs. performance: An overview of theories explaining trust in government, Second report: Quality and trust in government, Public Management Institute, Leuven 2002.

Coleman J.S., Foundations of Social Theory, Harvard University Press, Cambridge 1990.

Das T.K., Teng Bing S., The Risk-Based View on Trust: A Conceptual Framework, "Journal of Business and Psychology" 2004, Vol. 19(1), pp. 85-116.

Demmke Ch., Henökl T., Moilanen T., What are Public Services Good at? Success of Public Services in the Field of Human Resource Management, Study Commissioned by the Slovenian EU Presidency, Report to the 50th Meeting of the Directors-General of Public Services of the Member States of the European Union, 2008. http://www.eupan.eu/files/repository/Success_of_public_services_in_HRM.pdf.

Fukuyama F., Trust: The social virtues and the creation of prosperity, Free Press, New York 1995.

Giddens A., Risk and Responsibility, "Modern Law Review" 1999, Vol. 62(1), pp. 1-10.

Giddens A., The Consequences of Modernity, Cambridge University Press, Cambridge 1996.

Halligan J., Bouckaert G., Performance and trust: Developmental paths and optional directions, in: Change and continuity in public sector organizations - essays in honour of Per Lagreid, eds P.G. Roness, H. Sætren, Fagbokforlaget, Bergen 2009.

Hibbing J.R., Theiss-Mors E., Stealth Democracy: Americans' Beliefs About How Government Should Work, Cambridge University Press, Cambridge 2002.

${ }^{42}$ R. Sobiech, op.cit. 
Inglehart R., Culture Shift in Advanced Industrial Society, Princeton University Press, Princeton 1990.

Kim S.E., The Role of Trust in the Modern Administrative State: An Integrative Model, "Administration \& Society" 2005, Vol. 37, pp. 611-635.

Klingemann H.D., Mapping Political Support in the 1990s: A Global Analysis, in: Critical Citizens: Global Support for Democratic Governance, ed. P. Norris, Oxford University Press, Oxford 1999, pp. 31-56.

Luhmann N., Trust and Power, John Wiley \& Sons, Chichester 1979.

Massoli L., Building Image of Public Administration: Practices and data from Italy, Public Administration Department, Innovative Public Services Group Meeting, Presidency of the Council of Ministers. Warsaw September 2011, Fact sheet presented to the Polish Presidency by the EUPAN Members' administrations.

Miller A.H., Listhoug O., Policy Preferences and political distrust: A Comparison of Norway, Sweden and the United States, "Scandinavian Political Studies" 1998, Vol. 21, pp. 161-187.

Nye J.S., The Decline of Confidence in Government, in: Why People Don't Trust Government, eds J.S. Nye, P.D. Zelikow, D.C. King, Harvard University Press, Cambridge 1997.

Public sector reform: The way forward, OECD, Paris 2005.

Rousseau D.M., Sitkin S.B., Burt R.S., Camerer C., Not so Different after all: A Cross-Discipline View of Trust, "Academy of Management Review" 1998, Vol. 23(3), pp. 393-404.

Sobiech R., Image and Attractivity of Central Government Administrations, A Report for European Social Dialogue Committee in Central Government Administrations, http://www. epsu.org/IMG/pdf/Image_CGA_report_17122012_EN.pdf.

Social Climate, Special Eurobarometer 370, The European Commission, 2011, http://ec.europa. eu/public_opinion/archives/ebs/ebs_370_en.pdf.

Sztompka P., Trust: A cultural resource, in: The Moral Fabric in Contemporary Societies, eds G. Skapska, A. Orla-Bukowska, K. Kowalski, “The Annals of International Institute of Sociology. New Series" 2003, Vol. 9.

Sztompka P., Trust, Distrust and Two Paradoxes of Democracy, "European Journal of Social Theory" 1998, Vol. 1(1), pp. 19-32.

The call for innovative and open government. An overview of national initiatives, OECD, Paris 2011.

Trust in government, policy effectiveness and the governance agenda, in: Government at a Glance, OECD, OECD Publishing, 2013, http://dx.doi.org/10.1787/gov_glance-2013-6-en.

Trust in Society, ed. K.S. Cook, Russel Sage Foundation, New York 2001.

Tyler T., Why people obey the law, Yale University Press, New Haven 1990.

Ulbig S.G., Policies, Procedures, and People: Sources of Support for Government, "Social Science Quarterly” 2002, Vol. 83, pp. 789-809.

Van de Walle S., Van Roosbroek S., Bouckaert G., Strengthening Trust in Government: What Role for Government in the 21st Century: Annex: Data on trust in the public sector, Analytical annex prepared for the OECD meeting of the Public Governance Committee at ministerial level, Rotterdam 2005, https://irias.kuleuven.be/bitstream/123456789/84459/1/OECD_ trust_public_sector.pdf. 
Van Ryzin G., Outcomes, Process, and Trust of Civil Servants, "Journal of Public Administration Research and Theory" 2011, Vol. 21, Issue 4.

Williamson O.E., Calculativeness, Trust and Economic Organization, "Journal of Law and Economics" 1993, Vol. 30, pp. 131-145.

Zucker L.G., Production of trust: Institutional sources of economic structure 1840-1920, "Research in organizational behavior" 1986 , vol. 8, pp. 53-111. 